\title{
A multiplex RT-PCR for simultaneous differentiation of three viral pathogens of penaeid shrimp
}

\author{
Zhixun Xie $^{1, *}$, Yaoshan Pang ${ }^{1}$, Xianwen Deng ${ }^{1}$, Xiaofei Tang ${ }^{1}$, \\ Jiabo Liu1 ${ }^{1}$, Zhaofa Lu' ${ }^{2}$, Mazhar I. Khan ${ }^{3,4}$ \\ ${ }^{1}$ Guangxi Veterinary Research Institute, 51 You Ai North Road, Nanning, Guangxi 530001, PR China \\ ${ }^{2}$ Bureau of Fishery and Animal Husbandry, 135 Qi Xing Road, Nanning, Guangxi 530022, PR China \\ ${ }^{3}$ Department of Pathobiology \& Veterinary Science, University of Connecticut, 61 North Eagleville Road, Storrs, \\ Connecticut 06269-3089, USA
}

${ }^{4}$ Present address: Guangxi Veterinary Research Institute, 51 You Ai North Road, Nanning, Guangxi 530001, PR China

\begin{abstract}
A multiplex reverse transcription polymerase chain reaction (mRT-PCR) was developed and optimized to simultaneously detect 3 viral pathogens of shrimp. Three sets of specific oligonucleotide primers for Taura syndrome virus (TSV), white spot syndrome virus (WSSV) and infectious hypodermal and hematopoietic necrosis virus (IHHNV) were used in the assay. The mRT-PCR DNA products were visualized by gel electrophoresis and consisted of fragments of $231 \mathrm{bp}$ for TSV, $593 \mathrm{bp}$ for WSSV and $356 \mathrm{bp}$ for IHHNV. No specific bands of the same size were amplified from other penaeid shrimp pathogenic viruses or bacteria. As little as $10 \mathrm{pg}$ of TSV RNA and $100 \mathrm{pg}$ of WSSV DNA and IHHNV DNA could be detected using gel electrophoresis. Studies are in progress to further test the specificity and sensitivity of this mRT-PCR method on viral isolates, as well as on clinical samples.
\end{abstract}

KEY WORDS: Infectious hypodermal and hematopoietic necrosis virus $\cdot$ Multiplex $\cdot$ Polymerase chain reaction · Taura syndrome virus · White spot syndrome virus

Resale or republication not permitted without written consent of the publisher

\section{INTRODUCTION}

Infectious hypodermal and hematopoietic necrosis virus (IHHNV), Taura syndrome virus (TSV) and white spot syndrome virus (WSSV) are 3 major viral pathogens that infect penaeid shrimp (Bonami et al. 1990, 1997, Brock 1997, Lightner \& Redman 1998, Erickson et al. 2002). Mixed infections involving these viruses have been described in penaeid shrimps (Manivannan et al. 2002) and can cause high mortality, leading to economic losses that are detrimental to the shrimp farming industry (Lightner 1996, Plumb 1997, Wang et al. 1998).

Multiple diagnostic methods, such as histological examination, electron microscopy and histological studies using in situ hybridization, are required to detect and differentiate these viral pathogens (Takahashi et al. 1994, Lightner 1996, Plumb 1997, Lightner \& Redman 1998). However, these methods are time consuming and labor intensive. Molecular assays, such as DNA probes (Nunan \& Lightner 1997, Mari et al. 1998) and PCR methods, have been used for rapid and sensitive detection of these viruses (Lo et al. 1996, Wang et al. 1996, Nunan et al.1998, Kiatpathomchai et al. 2001, Tang et al. 2004). Traditionally, specific probes and PCR have been developed to detect a specific nucleic acid of one pathogen. Recently, real-time PCR assays have been developed to detect WSSV, TSV and IHHNV (Dhar et al. 2001, Yue et al. 2006) and to differentiate 2 viruses at a time (Tsai et al. 2002, Yang 
et al. 2006). Conventional singleplex PCR is potentially expensive and resource intensive, whereas the cost of real-time PCR equipment and the specific technical training required limit the usefulness of such assays as routine laboratory tests. In our study, we have developed a specific and sensitive multiplex PCR that can simultaneously detect and differentiate these 3 important viral agents infecting shrimp.

\section{MATERIALS AND METHODS}

Viral isolates and clinical samples. TSV, WSSV and IHHNV isolates are listed in Table 1.

Isolation of nucleic acids from viruses. RNA and DNA extractions from TSV, IHHNV and WSV isolates were carried out using Trizol according to the manufacturer's protocol (Invitrogen).

Extraction of nucleic acids from tissue samples. Total nucleic acid extracts from tissue samples from disease-free Penaeus vannamei were extracted by homogenizing $10 \mathrm{mg}$ frozen infected tissues (stomach tissue homogenate) in $700 \mu$ lysis buffer containing $2 \%$ hexadecyl-trimethy-ammonium-bromide, $1.4 \mathrm{mM}$ $\mathrm{NaCl}, 20 \mathrm{mM}$ EDTA and $20 \mathrm{mM}$ Tris-HCl (pH 7.5), adding isoamyl alcohol to the final concentration of $2.5 \%$. Samples were incubated at room temperature for $1 \mathrm{~h}$. After incubation, $500 \mu \mathrm{l}$ phenol/chloroform (1:1) was added to each sample and mixed vigorously by vortexing and incubated for $15 \mathrm{~min}$ at room temperature. The mixtures were centrifuged at $12000 \mathrm{rpm}$ $(14000 \times g)$ for $15 \mathrm{~min}$ at $4^{\circ} \mathrm{C}$, and supernatants were transferred to $1.5 \mathrm{ml}$ tubes. Equal volumes of isopropanol were added to precipitate the nucleic acid, and the mixtures were inverted several times during

Table 1. Shrimp pathogens and field samples used in this experiment. TSV: Taura syndrome virus; WSSV: white spot syndrome virus; IHHNV: infectious hypodermal and hematopoietic necrosis virus; GXPRC: Guangxi, People's Republic of China; CIVDC: China Institute of Veterinary Drug Control

\begin{tabular}{ll}
\hline Shrimp pathogens & Source \\
\hline TSV (GXPRC/1/02) & Beihai, Guangxi, PR China \\
TSV (GXPRC/1/03) & Hepu, Guangxi, PR China \\
TSV (GXPRC/2/03) & Qinzhou, Guangxi, PR China \\
WSSV (GXPRC/1/02) & Beihai, Guangxi, PR China \\
WSSV (GXPRC/2/02) & Hepu, Guangxi, PR China \\
WSSV (GXPRC/1/03) & Qinzhou, Guangxi, PR China \\
IHHNV (GXPRC/1/03) & Beihai, Guangxi, PR China \\
IHHNV (GXPRC/2/03) & Hepu, Guangxi, PR China \\
IHHNV (GXPRC/1/04) & Qinzhou, Guangxi, PR China \\
Vibrio spp. (extracted DNA) & CIVDC, Beijing, PR China \\
Streptococcus spp. (extracted DNA) & CIVDC, Beijing, PR China \\
Yellow head virus (extracted RNA) & CIVDC, Beijing, PR China \\
Tissue sample & Disease-free Penaeus vannamei \\
\hline
\end{tabular}

the incubation at room temperature for $15 \mathrm{~min}$. The mixtures were centrifuged at $12000 \mathrm{rpm}(14000 \times \mathrm{g})$ for $15 \mathrm{~min}$ at $4^{\circ} \mathrm{C}$. Pellets were rinsed with $500 \mu \mathrm{l} 75 \%$ ethanol, then air dried for about $15 \mathrm{~min}$.

Pellets containing nucleic acid were resuspended in $20 \mu \mathrm{l}$ of RNase-free distilled water. The purity and concentration of DNA and RNA were determined spectrophotometrically by 260:280 nm ratios and $260 \mathrm{~nm}$ readings, respectively, using a spectrophotometer (Shimadzu UV-1200), and the nucleic acids were stored at $-20^{\circ} \mathrm{C}$ until use. Extracted DNA of Vibro spp. and Streptococcus spp. and RNA of yellow head virus were kindly provided by the China Institute of Veterinary Drug Control, Beijing.

Oligonucleotide primers. Three sets of primers that specifically amplify WSSV, IHHNV and TSV were used. WSSV primers GATGAGACAGCCAAGTTGTTAAAC and GCATCAACTTCCACAGCTTTATC amplify 593 bp DNA product, IHHNV primers ATCGGT GCACTACTCGGA and TCGTACTGGCTGTTCATC amplify 356 bp DNA product and TSV primers TCAATGAGAGCTTGGTCC and AAGTAGACAGC CGCGCTT amplify 231 bp DNA product. The primers for WSSV were designed using DNASTAR software against a conserved region of the WSSV genomic sequence (GenBank No. AF 369029) that encodes for a non-structural protein. IHHNV primers were from a region in between the non-structural and the structural protein-coding regions of the genome (GenBank No. AF 218266). TSV-specific primers had been reported previously in the literature (Nunan et al. 1998). All 3 sets of primers were synthesized at Takara Shuzo Stet. Primers were diluted to a final

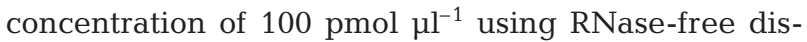
tilled water and stored at $-20^{\circ} \mathrm{C}$.

Multiplex reverse transcription polymerase reaction (mRT-PCR). The mRT-PCR consisted of a 2-step procedure as described (Pang et al. 2002), which includes reverse transcription (RT) and PCR amplification. The RTPCR kit (Takara Shuzo Co.) was used for all RT and PCR amplifications. RT is performed in $20 \mu \mathrm{l}$ volumes, each RT mixture containing $5 \mathrm{mM} \quad \mathrm{MgCl}_{2}$; $500 \mathrm{mM} \mathrm{KCL} ; 100 \mathrm{mM}$ Tris HCL, pH $8.3 ; 1 \mathrm{mM}$ of each deoxyadenosine triphosphate (dATP), de-oxythymidine triphosphate (dTTP), deoxycytidine triphosphate (dCTP) and deoxyguanosine (dGTP); 2 U RNase inhibitor; $0.25 \mathrm{U}$ avian myeloblastosis virus (AMV) reverse transcriptase; and 1.25 pmol of TSV forward primer. Different concentrations of DNA or RNA 
of WSSV, IHHNV and TSV in $4 \mu \mathrm{l}$ volumes were then added to the mixture. Diethylpyrocarbonate (DEPC)treated distilled $\mathrm{H}_{2} \mathrm{O}$ was added to bring the final volume to $20 \mu \mathrm{l}$. RT was performed in a thermal cycler (Model 9600, Perkin Elmer Cetus) for 1 cycle at $42^{\circ} \mathrm{C}$ for $25 \mathrm{~min}, 99^{\circ} \mathrm{C}$ for $3 \mathrm{~min}$ and $4^{\circ} \mathrm{C}$ for $5 \mathrm{~min}$.

For the multiplex PCR reaction, $5 \mathrm{mM} \mathrm{MgCl}_{2}$; $500 \mathrm{mM} \mathrm{KCL} ; 100 \mathrm{mM}$ Tris HCL, pH 8.3; $10 \mathrm{mM}$ each dATP, dTTP, dCTP and dGTP; 0.5 pmol of each WSSV and IHHNV forward and reverse primers with TSV reverse primer; and 1.25 U TaKaRa LA Taq (Takara Shuzo Co.) polymerase were added in the above RT reaction tubes, and $50 \mu \mathrm{l}$ of the total volume was obtained by adding DEPC-treated distilled water. The mPCR was carried out in the same thermal cycler used for RT. After extensive preliminary trials with different annealing temperatures and times and with various concentrations of DNA and RNA, the thermal cycler was programmed for optimum conditions. The optimized cycling protocol consisted of an initial denaturing at $94^{\circ} \mathrm{C}$ for $5 \mathrm{~min}$, then 35 cycles that each consisted of denaturing at $94^{\circ} \mathrm{C}$ for $45 \mathrm{~s}$ and annealing and extension at $68^{\circ} \mathrm{C}$ for $2 \mathrm{~min}$. The sample was then heated to $68^{\circ} \mathrm{C}$ for $10 \mathrm{~min}$ for a final extension. The negative control did not contain template cDNA/DNA; it consisted of PCR master mix, all 3 sets of primers and de-ionized water.

Detection of amplified mRT-PCR products. Agarose gel electrophoresis was used to detect mRT-PCR nucleic acid products. A volume of $10 \mu \mathrm{l}$ of amplified product was subjected to $1 \%$ agarose horizontal gel electrophoresis with $0.5 \mu \mathrm{g}$ ethidium bromide $\mathrm{ml}^{-1}$ at $5 \mathrm{v} / \mathrm{m} \mathrm{V}$ using Tris-borate buffer (45 mM Tris-borate, 1 mM EDTA) (Sambrook et al. 1989). Gels were visualized and photographed using the Bio-Vision Post-Electrophoresis Instrument (Vilber Lourmat).

Specificity and sensitivity of the mRT-PCR. To determine the specificity of the mRT-PCR, the amplified DNA fragments from TSV, WSSV and IHHNV were cloned into the pMD18-T cloning vector (Takara Shuzo Co.). The recombinant plasmid DNA was sequenced in an automated DNA sequencer (Takara Shuzo Co.), and the sequence data were analyzed by DNASTAR software and compared with the corresponding sequences in GenBank. For further confirmation of specificity, $200 \mathrm{ng}$ of RNA from yellow head disease virus and $200 \mathrm{ng}$ of DNA from both Vibrio spp. and Streptococcus spp., as well as same amount of nucleic acid isolated from specificpathogen-free (SPF) Penaeus vannamei were also tested by mRT-PCR. Sensitivity of this mPCR was determined by making 10 -fold dilutions of a mixture containing $100 \mathrm{ng}$ of template of each TSV RNA, WSSV DNA and IHHNV DNA.

\section{RESULTS AND DISCUSSION}

A method of mRT-PCR was developed and optimized to detect and simultaneously differentiate 3 viral pathogens in a single tube reaction through 35 cycles of PCR. The optimal mRT-PCR yielded 3 amplified fragments, i.e. $231 \mathrm{bp}$ for TSV, $593 \mathrm{bp}$ for WSSV and $365 \mathrm{bp}$ for IHHNV (Figs. 1 \& 2). The identity of each mRT-PCR product was further confirmed by DNA sequencing. The sequences of the mRT-PCR products were matched to those of TSV, WSSV and IHHNV based on sequence data in GenBank using DNASTAR software. The mRT-PCR method was found to be specific and to be able to detect and differentiate TSV, WSSV and IHHNV. No amplifications were observed when nucleic acid from Vibrio spp. and Streptococcus spp., as well as SPF Penaeus vannamei were used as mRT-PCR templates (Fig. 1). The detectable limit of the mRT-PCR was $10 \mathrm{pg}$ for TSV and100 pg for both WSSV and IHHNV (Fig. 2).

Throughout development of the mRT-PCR method, various modifications were made to the annealing temperature, extension time, cycle quantity and primer concentrations in order to obtain optimal conditions.

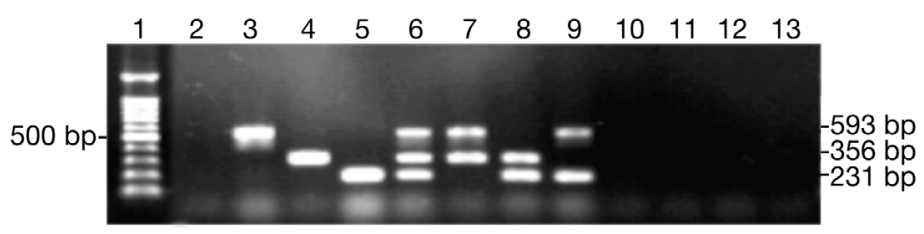

Fig. 1. Specificity of multiplex RT-PCR. Lane 1: 100 bp DNA size marker; Lane 2: specific pathogen-free (SPF) Penaeus vannamei; Lane 3: WSSV (GXPRC/1/02); Lane 4: IHHNV (GXPRC/1/03); Lane 5: TSV (GXPRC/1/02); Lane 6: WSSV (GXPRC/1/02) + IHHNV (GXPRC/1/03) + TSV (GXPRC/1/ 02); Lane 7: WSSV (GXP- RC/1/02) + IHHNV (GXPRC/1/03); Lane 8: IHHNV (GXPRC/1/03) + TSV (GXPRC/1/02); Lane 9: WSSV (GXPRC/1/02) + TSV (GXPRC/1/02); Lane 10: yellow head disease virus; Lane 11: Vibrio spp.; Lane 12: Streptococcus spp.; Lane 13: buffer control. For pathogen abbreviations, see Table 1

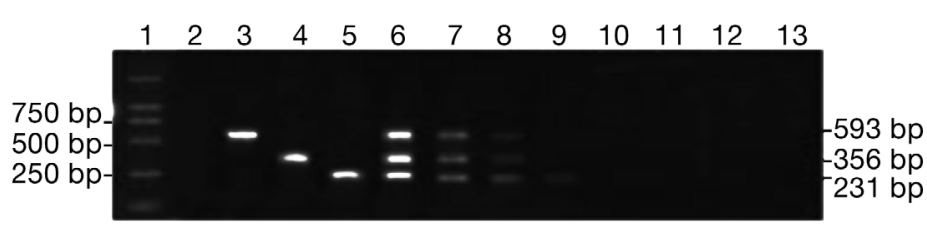

Fig. 2. Sensitivity of multiplex RT-PCR. Lane 1: 200 bp DNA size marker; Lane 2: SPF Penaeus vannamei; Lane 3: WSSV (GXPRC/2/02); Lane 4: IHHNV (GXPRC/1/04); Lane 5: TSV (GXPRC/2/03). Lanes 6 to 13: different amounts of DNA or RNA from each of WSSV, IHHNV and TSV; Lane 6: $100 \mathrm{ng}$; Lane 7: 10 ng; Lane 8: 100 pg; Lane 9: 10 pg; Lane 10: 1 pg; Lane 11: $100 \mathrm{fg}$; Lane 12: $10 \mathrm{fg}$; Lane 13: $1 \mathrm{fg}$. For pathogen abbreviations, see Table 1 
No spurious PCR amplification reactions among any shrimp or other pathogens were noted with various amounts of RNA and DNA mixtures. All negative controls included RNA/DNA samples from disease-free Penaeus vannamei. DNASTAR software analysis indicated that the mRT-PCR-amplified DNA products were similar to the TSV-, WSSV- and IHHNV-specific gene sequences.

An mRT-PCR that can rapidly identify and differentiate these 3 viral infections, and possibly detect multiple infections, will be useful for the control of viral diseases in shrimp. Further studies are in progress to test the specificity and sensitivity of this mRT-PCR method on viral isolates of TSV, WSSV and IHHNV from various diagnostic and research laboratories, as well as on clinical samples originating from shrimp farms in South China.

Acknowledgements. This work was supported by the Guangxi Science and Technology and Guangxi Aquaculture and Animal Husbandry Bureau. The authors thank Dr. Salvatore Frasca Jr. for his critical review of the manuscript.

\section{LITERATURE CITED}

Bonami JR, Trumper B, Mari J, Brehelin M, Lightner DV (1990) Purification and characterization of the infectious hypodermal and haematopoietic necrosis virus of penaeid shrimps. J Gen Virol 71:2657-2664

Bonami JR., Hasson K, Mari J, Poulos B, Lightner DV (1997) Taura syndrome of marine penaeid shrimp: characterization of the viral agent. J Gen Virol 78:313-319

Brock JA (1997) Special topic review: Taura syndrome, a disease important to shrimp farms in the Americas. World J Microbiol Biotechnol 13:415-418

Dhar AK, Roux MM, Klimpel KR (2001) Detection and quantification of infectious hypodermal and hematopoietic necrosis virus and white spot virus in shrimp using realtime quantitative PCR and SYBR green chemistry. J Clin Microbiol 39:2835-2845

Erickson HS, Zarain-Herzberg M, Lightner DV (2002) Detection of Taura syndrome virus (TSV) strain differences using selected diagnostic methods: diagnostic implications in penaeid shrimp. Dis Aquat Org 52:1-10

Kiatpathomchai W, Boonsaeng V, Tassanakajon A, Wongteerasupaya C, Jitrapakdee S, Panyim S (2001) A nonstop, single-tube, semi-nested PCR technique for grading the severity of white spot syndrome virus infections in Penaeus monodon. Dis Aquat Org 47:235-239

Lightner DV (1996) The penaeid shrimp viruses IHHNV and TSV: epizootiology, production impacts and role of international trade in their distribution in the Americas. Rev Sci Tech Off Int Epizoot 15:579-601

Editorial responsibility: Timothy Flegel,

Bangkok, Thailand
Lightner DV, Redman RM (1998) Shrimp diseases and current diagnostic methods. Aquaculture 164:201-220

Lo CF, Leu JH, Ho CH, Chen CH and 8 others (1996) Detection of baculovirus associated with white spot syndrome (WSBV) in penaeid shrimps using polymerase chain reaction. Dis Aquat Org 25:133-141

Manivannan S, Otta SK, Karunasagar I, Karunasagar I (2002) Multiple viral infection in Penaeus monodon shrimp postlarvae in an Indian hatchery. Dis Aquat Org 48:233-236

Mari J, Bonami JR, Lightner DV (1998) Taura syndrome of penaeid shrimp: cloning of viral genome fragments and development of specific gene probes. Dis Aquat Org 33: $11-17$

Nunan LM, Lightner DV (1997) Development of a nonradioactive gene probe by $\mathrm{PCR}$ for detection of white spot syndrome virus (WSSV). J Virol Methods 63: 193-201

Nunan LM, Poulos BT, Lighter DV (1998) Reverse transcription polymerase chain reaction (RT-PCR) used for the detection of Taura syndrome virus (TSV) in experimentally infected shrimp. Dis Aquat Org 34:87-91

Pang Y, Wang H, Girshick T, Xie Z, Khan MI (2002) Development and application of a multiplex polymerase chain for avian respiratory agents. Avian Dis 46:691-699

Plumb JA (1997) Trends in freshwater fish disease research. FAO Aquacult News 16:35-47

Sambrook J, Fritsch EF, Maniatis T (1989) Molecular cloning: a laboratory manual, 2nd edn. Cold Spring Harbor Laboratory Press, Cold Spring Harbor, NY

Takahashi Y, Itami T, Kondo M, Maeda M, Fujii R, Tomonaga S, Supamattaya K, Boonyaratpalin S (1994) Electron microscopic evidence of bacilliform virus infection in Kuruma shrimp (Penaeus japonicus). Fish Pathol 29:121-125

Tang KFJ, Wang J, Lightner DV (2004) Quantitation of Taura syndrome virus by real time RT-PCR with TaqMan assay. J Virol Methods 115:109-114

Tsai JM, Shiau LJ, Lee HH, Chan PW, Lin CY (2002) Simultaneous detection of white spot syndrome virus (WSSV) and Taura syndrome virus (TSV) by multiplex reverse transcription-polymerase chain reaction (RT-PCR) in Pacific white Penaeus vannamei. Dis Aquat Org 50:9-12

Wang SY, Hong C, Lotz JM (1996) Development of a PCR procedure for the detection of Baculovirus penaei in shrimp. Dis Aquat Org 25:123-131

Wang YC, Lo CF, Chang PS, Kou GH (1998) White spot syndrome associated virus (WSSV) infection in cultured and wild decapods in Taiwan. Aquaculture 164:221-231

Yang B, Song XL, Huang J, Shi CY, Liu QH, Liu L (2006) A single step multiplex PCR for simultaneous detection of white spot syndrome virus and infectious hypodermal and haematopoietic necrosis virus in penaeid shrimp. J Fish Dis 29:301-305

Yue ZQ, Liu H, Wang W, Lei ZW, Liang CZ, Jiang YL (2006) Development of real-time polymerase chain reaction assay with TaqMan probe for the quantitative detection of infectious hypodermal and hematopoietic necrosis virus from shrimp. AOAC Int J 89:240-244

Submitted: September 29, 2006; Accepted: February 2, 2007 Proofs received from author(s): April 5, 2007 